\title{
A Critical Inquiry into the Concept of East Asia (China, Japan, Korea) of the Past Centuries: In the Context of Asia's Image
}

\author{
Chi Won CHOI \\ Korea University, Seoul, Korea
}

\begin{abstract}
In East Asia - China, Japan and Korea - there has always existed both a desire and hope for regional integration. Europe has been, and remains, a symbolic model of regional integration at political, economic, social and cultural levels. The hope to achieve a similar regional community has provided the momentum and impetus to think about a more general idea of East Asia: An idea that might substantiate the entire region's future prospects. Previously, East Asia has not been overly successful at generating any knowledge or understanding of its own identity. It is therefore necessary to conduct an inquiry into the concept of East Asia. The complexity of knowledge about East Asia should be clarified. This paper interprets the concept of East Asia in past centuries, explains how people conceptualized East Asia in the broader context of the continent and evaluates its characteristic features.
\end{abstract}

Keywords: East Asian community, Toyo (East Asia), Asia’s image, Imagining Asia, Asianism, orientalism

\section{Problematic}

The term East Asia or Northeast Asia is in wide currency. This concept has a nuanced meaning. China usually uses the term Asia instead of Northeast Asia. Japan prefers East Asia to Asia or Northeast Asia. Korea frequently uses Northeast Asia ${ }^{1}$. Politicians and intellectuals have been interested in the idea of regional integration embodied by regional organizations such as ASEAN +3 or APEC. They argue that Northeast Asia (East Asia), like its European counterpart, needs to build cooperation to promote mutual interests. Though still evolving, the discussion covers the entire spectrum of issues, from economic, to social, cultural, political, military, environmental and more. The ideation inherent in this universal thinking reflects exactly what Höffe (1999) refers to as the idea of "world citizen", "world society", and "world republic", or what Habermas (2001) calls a "cosmopolitan situation" (pp. 21-39). ${ }^{2}$

East Asia or Northeast Asia envisions a regional community that is not restricted by a single nation's history. The new community of the future will call for each member country to cooperate with one another in the pursuit of the common good. But "East Asia" is a puzzling phrase in terms of the identity it represents. It could be an entity possessing a cultural, social and political affinity. Or it may be merely an imaginary space constructed by those who firmly believe in its existence.

It is necessary to clarify and present images, meanings and visions of East Asia that were formed

Chi Won CHOI, Research Professor, Peace and Democracy Institute, Korea University.

1 In this paper, I use East Asia to refer to the group of countries including China, Japan and Korea.

2 Corresponding to the situation of European post-national democratic constitution, Habermas (2001) emphasized basic elements in European identity-building: European civic society, a Europe-wide political public sphere, and common European political culture (p. 118). 
throughout history and serve as a basic idea for understanding the term. The following issues are specifically considered: how the West understands Asia in general (Chapter II); the implications of Western understanding for the self-conception of the three East Asian countries Japan, China and Korea (Chapter III); the intrinsic problem of history-based culture as their common means of understanding (Chapter IV). In sum, this paper based on an ideational approach - has a limited objective to provide a framework for understanding problems related to East Asia in the context of regional integration and stimulate and contribute to the kind of study necessary for any intellectual advancement in this field.

\section{The Western Understanding of Asia and Its Meaning for East Asia}

Asian identity is closely related to the way in which the West understands other regions of the world. The Christian religion has served as the foundation of Western identity. European scholars and intellectuals developed a dichotomy: rational and developed Europe and irrational and undeveloped Asia. Adam Smith, Georg W. F. Hegel, Karl Marx (who formed the famous concept of the Asiatic mode of production), and Max Weber (in the name of rationalism) typically constructed a dichotomous framework. Asia was conceptualized in contrast with or even in opposition to Europe. ${ }^{3}$

There is a long tradition in the West of confirming Western identity by defining identities of the non-Western world (Perkins, 2004). This is evident in the practice of Christianity. One could argue for example that Western identity "overlaps with Christian identity" (Pieris, 1988, p. 47) or that a "shared Christian origin" is the most important unifying and identifying element of the West (Vattimo, 2002, p. 74). The idea is to contrive a drastic contrast between the West and the non-Western world by emphasizing the Christian elements supposedly distinct from elements of other religions. The so-called clash of civilizations (Huntington, 1993; 1996) is a variant of this dichotomy.

On occasion, Asia was an object of fascination and respect for many philosophers. For example Leibniz and Montesquieu used China as a criterion for criticizing European society. Nietzsche regarded Buddhism as superior to Christianity. Despite idealization, the fact remains that the characterization of Asia is incomplete and based on the West. Differentiating the self (the West or Europe) from the other (Asia) is an intellectual process whereby a dichotomy as an ideological construct is produced; Europe stands for a modern, advanced stage of civilization and Asia, a traditional, less developed one. It can be called a "Eurocentric understanding of culture" (Amin, 1989, p. 103).

The Western understanding of Asian identity covers a wide range of subjects. It is an intellectual source of the creation and re-creation of Asia's image. ${ }^{4}$ But it also provides a framework for understanding East Asia, especially when it refers to the questions of backwardness. To wit: As Asia falls under the category of a static and unchanging region, so does East Asia. That is where the difficulty lies: There is a bit of truth in it, which creates a dilemma wherein something seems to be fictitious but its existence is accepted as true.

So, when we look back on the past, it is conspicuous that Western political and legal ideas, which were

\footnotetext{
${ }^{3}$ One of the prominent representatives of this way of thinking was Karl A. Wittfogel (1957). He applied the concept of oriental society or oriental despotism to explain the political backwardness of Asia. China was adopted as powerful evidence for his argument.

4 See Edward Said's famous book Orientalism, which was first published in 1978. Western countries, while striving to create colonial empires, categorized the non-Western countries from their own perspective. The non-Western countries understood themselves based on this standard. Western countries not only ruled colonial territories, but they also exercised domination over the Weltanschauung. The totality of these kinds of attitudes can be called Orientalism.
} 
believed advanced and superior to traditional ones, served as powerful weapons to attack the existing order and values. For example, Freedom or liberty-ziyu in Japanese, ziyou (自由) in Chinese, zayu in Korean-was a concept that had no tradition in the history of East Asia. It acquired its first authentic political meaning in 1871/82 when Japanese Nakamura Masanao translated John Stuart Mill's On Liberty (1859). For Nakamura, "liberty" was a term that held no equivalent in either Chinese or Japanese (Garon, 2002, p. 217).

The case of China clearly shows that the Western notion of Asia, which addresses the lack of development, is not totally false and serves as a standard of reference to diagnose problems. The most vivid illustration was the cult of Science and Democracy in wusiyundong (五四運動, the May Fourth Movement) of 1919. The movement's best known advocate was Hu Shih who played a leading role in the New Culture Movement. In his xinxichao de yiyi (新思潮的意義, The Meaning of New Tide), he called for a "critical attitude" towards old values, emphasizing the necessity of "the introduction of new thought, new learning, new literature, and new beliefs from the West" (Hu, [1954]1963, p. 252). Science and democracy were symbolized as two teachers whom China should invite from the West. The acknowledgement of stagnation developed into an immanent logic of so-called quanpanxihua (全盤西化, the total Westernization). Confucianism, to which the backwardness of China was ascribed, was labeled and vehemently criticized as anti-scientific and anti-democratic.

The Western notion of Asia seems to remain an eternal presence that exerts influence on our worldview. We are to recognize it regardless of our denying it. The old image of Asia (the Orient), "to be unchanging was to be in decline" (Clark, 2004, p. 580), doesn't seem merely imaginary. It is worthwhile to note in this context that East Asian intellectuals of the late 19th and early 20th centuries, whether modernists (most of them were advocates of social Darwinism) or traditionalists, tried to reach an advanced stage of civilization as measured by European modernity. Under the banner of ziqiang (自強, self-strengthen), wenmingfazhan (文明發展, development of civilization) or shizheshengcun (適者生存, survival of the fittest), they mobilized people to attain a Western type of modernization (Machetzki, 1971; Park, 1979; Allen, 1990; Weiner, 1997; Osterhammel \& Petersson, 2000; Tikhonov, 2003).

\section{The Self-understanding: Japan, China, Korea}

Japan, China and Korea should re-evaluate old principles and values conserved with pride in the last decades of 19th century when they were brought into closer contact with the so-called Western Ocean. There emerged a group of concepts known as zhongtixiyong (中體西用, Chinese essence and Western utility), wakonyohsai (和魂洋才, Japanese soul and Western skill) and dongdosuhki (東道西器, Korean morality and Western tool). These self-concepts were bound together by a common belief in the spiritual superiority over the West. Utility (用), skill (才) and tool (器), which symbolized Western civilization, were regarded as belonging to barbarian and should be melted into a vessel of essence (體), soul (魂) and morality (道).

As seen above, the way East Asian countries understood the self and the other (the West) is characterized by a dualism between spirit and matter. These dichotomous schemes were developed by scholars trained in Confucian classics. Tseng Kuo Fan's "eclectic" attitude toward the Western civilization (Levenson, [1958] 1965, p. 57) formed the precedent. But it could be emphasized that their basic idea dwelled upon a Chinese traditional tributary worldview, a dichotomy of the Middle Kingdom and the rest of the world as barbarians. At the top of the Middle Kingdom, there was tianzi (天子, the son of heaven) as yuyiren (予一人, only-I-in-the-world), the sole representative of all mankind and culture. The rest of the world outside of his 
influence was categorized as uncivilized and barbarian. So, the principles of the barbarians (the West), were considered undeserving of respect because they lacked depth. The knowledge of the West was disdained as sensual pleasure or material culture, whereas Confucian values were recognized as fundamental elements of the identity. Even though the knowledge of the barbarians was so formidable as to discard the traditional worldview, it was considered useful only as a supplementary tool for $t i$ (essence) as the inviolable fundamental maxim for conduct (Levenson, 1968, p. 14, p. 65; Ro, 1989, pp. 30-31; Jensen, 1997, p. 260). Japan, which was scorned traditionally as a land of wokou (倭寇, dwarf pirates) by China and woegu by Korea, accepted the Western-originated image of Asia as static. It gave up sharing the conventional dichotomy of the East (spiritual principles, propriety) and the West (material principles, savageness), and worked out a plan to avoid being colonized. Japan became aware that East Asian countries, regardless of their self-esteem and glamorized old values, were destined to be colonized or semi-colonized under the hegemony of the West. Material development and the reorganization of the educational system, which would make a Western style of life and thinking possible, were emergent tasks.

Fukuzawa Yukichi, sensei (educator) of modern Japan, warned the Japanese against the ignorance of the West, believing that only the progress in knowledge and virtue would change Japan into the same state of civilization achieved in the West. ${ }^{5}$ He advocated the jitsugaku (practical knowledge) characteristic of Western learning. The greatest attention had to be paid to the fact that Japan, compared with the West, was only a "semi-developed" or "semi-civilized" country and that emulating Western civilization should be Japan's goal (Fukuzawa, 2008, p. 17, p. 59). His attitude toward the Western teachings was in stark contrast to that of Wei Yuan who-leaning upon a classical teaching of yiyizhiyi (以夷制夷, using barbarians against barbarians) — demonstrated in the 1840s that borrowing skills from the Western barbarians was indispensable to check and control them. ${ }^{6}$

Fukuzawa formulated a drastic worldview of datsua (脱亜, exit from Asia or de-Asianization). ${ }^{7}$ By datsua he meant on the one hand to discard traditional Confucian doctrines and to break off Japan's connection with a China-centered world order, and on the other hand to transform Japan into a modern nation-state state on the model of the West. Japan should refuse akuyuu (bad friend) of East Asia, namely China and Korea, which dwelled on "out-of-date modes", "old habits" and "vainglory" (Fukuzawa, [1885]1959). He held a vision concerned with the re-establishment of the regional identity as a whole: East Asia should revolve around a Japan that is getting out of uncivilized and inferior Asia. His yearning for Japan's joining the group of Western-style civilized countries led him to legitimate a Japan-led reorganization of the region. This victimized China and Korea, whether intended or not.

Okakura Kakuzo, better known as Okakura Tenshin, formulated the famous dictum "Asia is one". His understanding of Asia in the most extensive sense, with its poetic expressions, induced him to dream of "a single mighty web of the Asiatic races" (Okakura, [1903] 1920, p. 3). He believed in the existence of a unique element of Asian identity or the "common thought-inheritance" that made Asia worthy of the name. That was the "love for the Ultimate and Universal" (Okakura, [1903] 1920, p. 1).

\footnotetext{
5 This conviction was systematically manifested in his famous book gakumon no susume (An Encouragement of Learning) written and published between 1872 and 1876.

${ }^{6}$ Wei Yuan's idea was developed further two decades later by Feng Kuei Fen. Feng also acknowledged the strength of the Western barbarians surpassing China in making weapons and training soldiers and found it urgent to rely on barbarians for the better management of them.

7 Jijishinpo (News of Current Affairs) on 16th March 1885. About the characteristics of Jijishinpo (Uchiyama , 2009, p. 75).
} 
The conventional thought of Asia's spiritual priority over the West did not lose its meaning for him. Returning to and sharing Asia's own past (everything spiritual) was for him the groundwork for building up one Asia and the only way that Asia could revive itself, as well. But his intention was not merely for the sake of Asia: By positioning Japan in the broader context of Asia, he accentuated Japan's special meaning in relation to its neighboring countries, China and Korea. He confirmed that Japan represented "the history of Asiatic ideals", and it was "in Japan alone that the historic wealth of Asiatic culture can be consecutively studied through its treasured specimens" (Okakura, [1903] 1920, pp. 6-9). Most of all, Okakura expressed the opinion that Japan should become "the new Asiatic Power" whose mission was to "feel and revivify the dominant life of the old Asiatic unity" (Okakura, [1903] 1920, pp. 208-209). His idea of Japan as "new Asiatic Power" echoed Fukuzawa's idea of Japan as a civilized country. It casted a shadow on wars. In the late 1930s and the early 1940s, Japan expanded into Manchuria and Southeast Asia to realize an "old Asiatic unity", a dream of Asia-is-one.

Searching for a regional identity in Japan culminated in the most ambitious concept of Asia, daitoakyoeiken (大東亜共栄圈, the great zone for East Asian co-prosperity). ${ }^{8}$ Its ideological root might be traced back to the jingoistic ideas of Sato Nobuhiro in the late Edo period. Sato (2008) argued in his Kondo Hisaku (混同秘策, Confidential Plan of World Unification), "before Japan attempts to open other countries, it must first absorb China” (p. 339). Sato's Kondo Hisaku, which was written in 1823, influenced later imperialists to launch wars of aggression, describing the mission of empire and steps how to conquer the neighboring countries, Manchuria, Korea, Taiwan, China and finally the world (Masuda, 2000, pp. 65-67). For the purpose of fulfilling the needs of daitoa, two parts of Asia (Northeast Asia and Southeast Asia) should be politically, economically and culturally integrated. Keeping step with the aggressive expansion policies to liberate daitoa from the white imperialist countries, Britain and the United States, Japanese historians waged an "intellectual battle" to drag East Asian countries into a "new totality" schemed by Japan and hence reduce them to "incomplete variations" (Tanaka, 1993, p. 104) of Japan.

Chinese intellectuals also developed various notions of Asia. Li Da Zhao designed the concept of xinyaxiyazhuyi (新亞細亞主義, the new Asianism) in opposition to Western civilization the essence of which lay in the plunder of Asia. With this concept, he also waged an intellectual campaign directed against Japan's dayaxiyazhuyi (大亞細亞主義, the great Asianism) which, in his eyes, was just another expression of daribenzhuyi (大日本主義, the great Japanism) ${ }^{9}$ intended to build up Japan's Asia. Japan's dayaxiyazhuyi was interpreted as an insult to the brilliantly civilized country, zhonghua (中華, the Middle Kingdom). Thus, he asserted in Guominzazhi (國民雜誌, Citizen's Magazine, January 1919) that Asians must join together in espousing xinyaxiyazhuyi (新亞細亞主義) in place of [Japan's] dayaxiyazhuyi (Li, 1978, pp. 127-129). ${ }^{10}$ The problem of a China-centered worldview indeed remained untouched. And though Li's concept advocated one Asia and had a cosmopolitan purpose, it offered a very limited perspective because it assumed one Asia built only on the yellow race.

The most famous concept might be Sun Yat-Sen's dayazhouzhuyi (大亞洲主義, the great Asianism) formulated in 1924. Sun stood in a great intellectual tradition started with Lin Tse Hsu who strove to save China from moral and economic catastrophe by destroying British merchants' opium. Since Tseng Kuo Fan's

\footnotetext{
${ }^{8}$ This concept was advocated by the declaration of toashinchitsujo (東亜新秩序, the new East Asian order) of 1938.

9 The Great Asianism was grounded in Ukita Kazutami's idea of a Sino-Japanese alliance.

${ }^{10}$ Above all, he accentuated the aspect of the national liberation combined with a fundamental social change (Nohara, 1975).
} 
emphasis on the importance of Confucian morals, especially jing (敬, respectfulness) and xin (信, sincerity), Confucian principles had served as a backbone for Chinese scholars in treating barbarian affairs. Sun did not break with this precedent, either. Criticizing the reality of aggressive wars for which not only Japan but also the West should bear the responsibility, he developed dayazhouzhuyi (the great Asianism), which presented a striking contrast to Japan's concept of dayaxiyazhuyi (the great Asianism).

By dayazhou (大亞洲, the great Asia) he meant the rebirth of Asia. The method for its realization should not be the padao (霸道, the way of might) but wangdao (王道, the way of saints) based on three Confucian virtues, renyidaode (仁義道德, benevolence-justice-morality). He proclaimed wangdao as Asia's own and rejected padao as a characteristic of the West. When he urged the return to old Asia through wangdao, the old dichotomous theme, the moral superiority of Asia over the West, was recurrent in his idea of Asia: Asian values were regarded as the opposite of the Western materialism represented by airplanes, bombs and cannons, which were nothing but an expression of the way of might or cult of force that oppressed Asia. The Asia to which he referred was that of several hundred or thousand years ago when China was the cradles of world civilizations and when European countries, as a mark of their respect and esteem for China, willingly sent annual tributes. The only meaningful modern component in his idea was a version of the socialist internationalism, which called for an anti-West united front initiated by China, Japan and India. In fact, he tried to harmonize a Confucian ideal of world order with the modern commitment to provide Asian countries with a vision of liberation from Western imperialist countries. But his vision of Asia's liberation, which he might certainly consider a "happy event", contained a paradox; he neglected that the "happy event" was the expression of padao that he denied in favor of wangdao and that it was in reality a dark and foreboding moment that caused ruin and havoc in a small country such as Korea. ${ }^{11}$

Korea was categorized by China as dong-i (the East barbarian). Though described as barbarian, Korea was proud to have been called (in contrast to Japan) dongbangyeyuijiguk (the courteous country of the East) or dongfangliyizhiguo (東方禮儀之國) in Chinese. Korea accepted the cultural dominance of China and held fast to a dichotomous principle that had served for thousands of years as the foundation of Korea's worldview, namely zhonghua's (China's) superiority over all other surrounding barbarian countries. Mimicking the Chinese way of perception, Korea looked upon itself as a spiritual leader of the Confucian world order, i.e. as sozhunghwa (the little China) or xiaozhonghua (小中華) in Chinese. Countries that were not part of China and paid no tribute to it were regarded as beasts or barbarians. The scholars of silhak or sirak (實學, the practical learning) and bukhak (北學, the Northern learning) such as Hong Dae Yong, Park Ji Won and Chung Yak Yong, contributed to undermining the China-centered worldview and the dichotomous scheme of China/barbarians. But Korea never freed itself from the conventional thought of sadae (事大, serving the great) and mohwa (慕華, respecting China).

Traditionally, Korea took a scornful attitude towards Japan, a country of barbarians. This attitude was applied to understanding the West. In the eyes of Korean orthodox Confucian scholars, the Westerners were

\footnotetext{
${ }^{11}$ He urged the necessity of a unified yellow race against the white. Recalling the Russo-Japanese War of 1904-05, he said: "We regarded that Russian defeat by Japan as the defeat of the West by the East. We regarded the Japanese victory as our own victory. It was indeed a happy event" (Sun, 1965, pp. 306-312). In fact, in his category of Asia, there were India, Persia, Afghanistan, Arabia, Turkey, Bhutan and Nepal-but not Korea."He could not but restrain himself from criticizing Japanese expansionism in his speech and give more consideration to establishing a cooperative relationship between China and Japan while almost neglecting solidarity with weak and small nations such as colonized Korea. Just because of that, most Korean newspapers raised their voices instantly in disapproval of Sun's ideas, characterizing them as 'careless' and 'clumsy"' (Baik, 2002, pp. 280-281).
} 
nothing but a race that had no sense of propriety at all. Choi Ik Hyeon advocated a tenet, waeyangilche (倭洋一 體, Japan and the West belong to the same category of barbarians). Lee Hang Ro and Gi Jeong Jin developed a creed, wijeongcheoksa (衛正斥邪, uphold orthodoxy and repel heterodoxy). They all feared that Korea, the little China, would be turned into a country of beasts by Westerners and Japanese who were influenced by Western culture. They condemned Western knowledge as sahak (the wicked learning) opposed to the Confucian teaching and especially wangdo or wangdao in Chinese. Levenson's opinion that Chinese traditionalists, "whatever their opinion on westernization, had to agree, that Confucius was the sage of Chinese culture, and Confucianism its very essence" (Levenson, 1968, p. 81), is also applicable to understanding the tendency and behavioral patterns of Korean orthodox scholars.

Catholic missionaries, who were believed to be the ringleaders of polluting the beautiful land of Korea by bringing sahak, were persecuted. A prejudice that Korea had preserved a racial homogeneity throughout history played a considerable role in the perception of the West. The anti-Western attitudes evoked the sympathy of ordinary people. Under these circumstances, a nationalistic religion, known as donghak (Eastern learning), was founded in 1860 by Choi Je Woo. It was literally the opposite of seohak (Western learning). Donghak grasped accurately the public mind and later developed into an anti-Japanese and anti-Western mass movement.

The most effective way to resist the West was to bring up common images in the name of Asia or the East. Many figurative images were created for this purpose. A well-known one was sunmangchihan or chunwangchihan (唇亡齒寒) in Chinese (teeth feel cold when lips are ruined): The masses or intellectuals, whether Koreans, Japanese or Chinese, symbolized their own countries as either teeth or lips with the belief that teeth could not get along without lips. A mystic representation such as dongmundongjong or tongwentongzhong (同文同種) in Chinese (same culture and same race) was met everywhere in Korea, Japan and China. It was these metaphors that functioned as a fundamental idea of yeondae (Korean)/ liandai (Chinese)/rentai (Japanese), meaning solidarity. The idea of solidarity gained meaning especially in Korea after the Russo-Japanese War of 1905.

Ahn Jung Geun, the famous Korean nationalist and assassin of Ito Hirobumi, interpreted the Russo-Japanese War as struggle between the white and the yellow races, the West and the East. In his Dongyangpyeonghwaron (On Peace of the East) formulated in 1910, he appealed to the racial and cultural yeondae of three East Asian countries, Korea, Japan and China (Ahn, 1997). He considered the Russo-Japanese War the starting point of the regeneration of Asia as hwanginjong (the yellow race). It was natural that he worked out a concept of dongyang (東洋) (the East) liberated from the white race. He, as a pan-asianist, did not give up, as in the case of Sun Yat Sen, the hope for Japan's positive role in forming a close racial solidarity across Asia.

On the other hand, the idealization of the East or Asia as one yellow race was criticized by some intellectuals. Shin Chae Ho, for example, refused the naive belief that dongyangjuui (the Asianism) would naturally create a greater solidarity between China, Japan and Korea and save Korea or China from collapse. In his view, dongyangjuui was favored by the Japanese and the betrayers of Korea. He interpreted it as the pretext to usurp kukhon (the Korean national soul) (Shin, 1997).

In the early 20th century, Japan newly contrived the concept of Eastasia, toyo, in order to justify its hegemonic status in Asia. It was "a manifestation of Japan's view of itself and position in the world" (Tanaka, 1993, p. 12). A small country such as Korea was reduced to a subsidiary, a component of toyo set up by Japan. 


\section{History-based Culture as Common Self-Understanding of East Asian Countries}

In the context of the self-conception of the three East Asian countries of the past centuries, it is necessary to examine complex phenomena which are closely connected with a cultural process deeply rooted in history, from which people (whether Chinese, Japanese or Koreans) define their own identity. Take Korea as an example. Tangun is adored as the legendary founding father of the nation. Great emphasis is placed on the tale that Korea, surrounded by powerful foreign countries, has for centuries been subjected to their aggressions. Great events and great men and women are idealized; for example, admiral Yi Sun-Shin's HansanTaechup (a great victory at Hansan Island) and his famous Turtle Boat, the patriot Yun Bong Gil and Yu Gwan Sun arrested by Japanese police etc. Such national egocentricity, however, is by no means limited to one single nation. In China and Japan, one can also easily encounter such preoccupation with self-aggrandizement. The senses of national superiority, national self-esteem and national pride have built a culture of self-centeredness. The culture of self-centeredness, as an unexhausted power, has coined national characteristics full of founding myths and heroic narratives.

Ian Buruma (2005) criticized Korea's, Japan's and China's cultural mind as follows: "Koreans—not only in North but also in South - define their national identity with regard to the aggression of Japan. The legitimacy of Kim-dynasty in North Korea is thoroughly based on the mystical role of Kim Il Sung as heroic anti-Japanese resistant. The huge patriotic museum in South Korea [...], which was built under the last military regime, presents the same "tableaux" of demonic Japanese and Korean martyrs, as one sees this in the case of China [...] It is certain that the crime of the past [...] should never be forgotten. Nevertheless, there is something insane in the patriotic ideology of East Asia, especially in the Chinese ideology. The truth that China slaughtered its own people is still suppressed, while permanent anti-Japanese feelings are instigated [...]"

Cultural practice as self-conception has provided the best means for preserving the national identity. People feel themselves to be Korean, Japanese or Chinese and find comfort and meaning by doing so. Schools and armies train them as carriers of national identity, i.e. sons and daughters of the fatherland who are always ready to sacrifice themselves. Great heroes are presented as if they would realize the dream of the nation. A nation becomes, as Renan (1993) criticized, a soul that will always attain a common greatness and fame (pp. 290-311).

Inculcating patriotic doctrines into people's minds and fabricating a community of destiny called nation - this modern pathology appeared not only in European countries. It also appeared in East Asian countries, accompanied by the state's attempt to revive the past by stirring up national pride. The state presents itself as the embodiment or epitome of a moral order. As Eder (1991) argues, the state appeals to origin (or birth) and uses the traditional identifications to ensure the basis of the co-ordination of action and opinion of people (pp. 260-261). China's recent search for national identity, dongbeigongcheng [Northeast Project: A Series of Studies on the History of the Northeast Provinces (東北工程)], serves as a good example of this. It is a state-led project with a conscious aim of propagandizing China's great civilization of the past. It evokes the past in a way that arouses nostalgias for national pride to extend its cultural hegemony to neighboring countries.

\section{Critical Assessments}

There are common problems in the understanding of Asia/East Asia: antiquated world views, racial antipathy and false ideas of regional unity; the greater the antipathy against the West, the stronger the sympathy 
for us, i.e. a consciousness of being Asian. The concept of the East, Asia or East Asia had a special meaning in this respect. Whatever the intention might be, the usage of this concept had one common aim: opposing the West. Above all, the greatest problem lies in the way that the notion of Asia or the East is first glorified and idealized and then equated with one specific country. Each country conceives of Asia or the East as an ideal for forming a new picture of Asia, but Asia, once idealized, exists only for the sake of our fatherland.

Attempts to create a regional identity in East Asia have proved to be futile. Above all, there remains a tragic history in which China and Korea were coercively drawn into Japan's project of building a pan-Asiatic empire. Japan's concept lacks validity. If Japan's concept of daitoakyoeiken, in the true sense of the word, had built links between people, across cultures and beliefs, it could have become the first meaningful clue for further exploring and understanding a regional identity. It legitimated only Japan's view by subordinating other countries to an abstract notion of Asia or East Asia. China's attempt to define Asian identity in the hope of recovering old values is not so convincing. The idea of wangdao as the foundation of Asian identity is controversial. Besides, it tried to awaken the Chinese to a sense of superiority by overemphasizing China's status and responsibility in Asia and by defending China's Asia. Especially, Sun's concept had much in common with Fukuzawa's. They both aimed at re-establishing the identity of Asia. Sun's theme, however, was not the exit from Asia but the return to Asia. The return to Asia was also Okakura Tenshin's theme. Korea's concept lacks substance and remains merely a conventional idea of unifying the yellow race.

Apart from these architectures of complexity, perhaps one might argue in defense that values specific to East Asian countries, especially Confucianism, could serve as episteme (root) for generating an identity concept. It is this form of epistemological speculation by which East Asia is constituted as a space sharing a common cultural heritage of Confucian spirit. In 1980s and 1990s, the elements of Confucian ethics (for example, idea of harmony, respect for elder and authority, family-oriented and group-minded attitude, the spirit of self-sacrifice) appeared in discourses to explain Asia's successful economic development and were proclaimed as approved Asian values. Ideas such as post-Confucian collectivism (MacFarquhar, 1980), post-Confucian ethics (Berger, [1988]1999) or new Confucianism (Bell, 2008) were attractive enough to suggest that Confucianism as norm and foundation might play an important role in conceptualizing a regional identity.

It is quite true that merits of Confucian values need to be reevaluated, as De Bary (2000) argues. But the Confucianism as the core of East Asian values is "a vague concept" (Kim, 2008, p. 4). Furthermore, historical experiences show that attempts at a practical application of Confucian principles resulted in a mystification of reality. In Japan, Confucianism was used to legitimate the patriarchal rule of the Meiji emperor, especially since the promulgation of the notorious kyoikuchokugo (the Royal Message of Education) of 1890. Based on Confucian ethics Being loyal to the ruler (chu in Japanese, zhong in Chinese, chung in Korean) and Being dutiful to parents and seniors (kou in Japanese, xiao in Chinese, hyo in Korean), Japan was able to define itself as single family harmonized between the imperial family and subjects. In Korea, Confucianism also played a significant role, for example, in legitimating the military dictatorship of Park Chung Hee. With the help of internalized Confucian moral codes, he could create an image of himself as a benevolent ruler and successfully mobilize people for national identity-building.

The belief that Confucianism should be a common ground for identity-building reminds us of Feng Kuei Fen. Feng (1954) argued more than 150 years ago: "If we let Chinese ethics and famous teachings serve as an original foundation, and let them be supplemented by the methods used by the various [Western] nations for the attainment of prosperity and strength, would it not be the best of all procedures?" (p. 52). The hold of the past is 
too strong in East Asia. Traumas of the past have been set in the hearts of the people. Bad memories of history have hindered productive thinking for the future. If Japan were forced to reckon, as Germany was, with their crimes, perhaps the ghosts of history might haunt Asia much less than they do today. The situation seems to be somewhat different in Europe. Europe is reborn as the European Union. ${ }^{12}$ There is a vivid cultural tradition of the Enlightenment that does not embody virtues, spirits and sentiments of one single nation. It is no accident that Hobsbawm (2001) held the view that one of the most important elements in European identity-building is the legacy of the Enlightenment (p. 54).

Compared with Europe, the prospects for East Asia are discouraging. Even from the aspect of global democracy, the situation is not so optimistic. Above all, China is still far from democracy. Confucianism serves here as an expedient instrument for hardening the ground of national identity. Today, Confucianism has a special meaning for China, the suzerain state of Confucianism. It is a cornerstone underlying the building of national identity, xinzhonghuazhuyi (新中華主義, the new Sino-centrism). In China, socialism as history has already lost its function as magistra vitae. Instead, Confucianism is providing the most effective instrument for opposing the evils of the West and protecting the social disintegration. When Confucianism exists only for solidifying a national identity, i.e. zhonghuadajiazu (中華大家族, the great Chinese family), it is no more magistra vitae for East Asia. Reestablishing “Zhonghua (中華) Order is a myth” (Tang, 2002, p. 26). In China, this myth seems to be perpetuated by Confucianism. Considering all these, one might say the prospects for East Asia are located "somewhere between views of procedural divergence and fundamental skepticism" (Kim, 2009 , p. 295). Or should one, in these day of world democracy, still say that "the politics of imagining Asia" (Wang, 2007) will not betray the future?

The term East Asia or Northeast Asia envisions a regional community, denoting an identity concept. Until now, no meaningful clue has been found to answer the puzzle whether East Asia could generate a regional identity, free from the binding effects of the past. Europe has already become a term that substantiates such a view. So if one should ask if there is magistra vitae for the regional integration, the answer would be the European experience. The European experience shows that regional identity-building should begin with a consideration on the individual level of fundamental human rights, from which more generalized ideas can be obtained in a regional and supranational level. The question of "what is a general idea of East Asia" is a truly relevant one to gauge the current state as well as the future direction of world citizen, world society, world republic and cosmopolitan situation.

\section{References}

Ahn, J. G. (1997). Dongyangpyeongwharon [On peace of the east]. In C. Won-Sik \& B. Young-Seo (Eds.), Dongasiainui “Dongyang” insik [Cognition of the East by Asian] (pp. 205-215). Seoul: Munhakkwa Jiseongsa.

Allen, C. T. (1990). Northeast Asia centered around Korea: Ch'oe Namson's view of history. The Journal of Asian Studies, 49(4), 787-806.

Amin, S. (1989). Ansätze zu einer nicht-eurozentrischen Kulturtheorie. Prokla, 19, 97-108.

Baik, Y. S. (2002). Conceptualizing "Asia" in modern Chinese mind: A Korean perspective. Inter-Asia Cultural Studies, 3(2), 277-286.

\footnotetext{
12 It could be argued that nationalism played a major role in WWI and WWII in Europe. It wasn't until after WWII-and the forced punishment of Nazi leaders by the allied nations led by America and the subsequent engagement efforts by France and West Germany (whom had been national enemies for centuries) in the following decades - that negative nationalism became significantly reduced. Meanwhile in East Asia, the US pointedly did not go through the process of punishing Japanese imperialists or force contrition after WWII, perhaps because it was inconvenient for their plans for the Cold War. This could be a critique of the idea that Asia is incapable of banishing its historical demons and culturally more susceptible to nationalism?
} 
Bell, D. A. (2008). China's new confucianism: Politics and everyday life in a changing society. Princeton and Oxford: Princeton University Press.

Berger, P. L. (1988] 1999). An East Asian development model? In P. L. Berger \& H. H. M. Hsiao (Eds.), In search of an East Asian development model (pp. 3-23). New Jersey: Transaction Publishers.

Buruma, I. (2005). Nationalisten in fernost. Der chinesische Haß auf Japan ist Ausdruck der verpaßten Liberalisierung. Die Welt, Don. 14. April. Retrieved from http://www.welt.de.

Clark, J. C. D. (2004). Is there still a west? The trajectory of a category. Orbis, 48(4), 577-591.

De Bary, W. T. (2000). Asian values and human rights: A confucian communitarian perspective. Cambridge, Mass.: Harvard Univ. Press.

Feng, K. F. (1954). On the adoption of western knowledge. In S. Y. Teng \& J. K. Fairbank (Eds.), China's response to the West: A documentary Survey 1839-1923 (pp. 51-57). Massachusetts: Atheneum.

Fukuzawa, Y. (1959). Datsuaron (On exit from Asia, orig. 1885). In Fukuzawa Yukichi Zenshu (Complete works), vol. 10. Tokyo: Iwanami Shoten.

Fukuzawa, Y. (1969). An encouragement of learning. (D. A. Dilworth \& U. Hirano, Trans.). Tokyo: Sophia Univ. Press.

Fukuzawa, Y. (2008). An outline of a theory of civilization. (D. A. Dilworth \& G. C. Hurst trans.). New York: Columbia Univ. Press.

Garon, S. (2002). Japan: State, society, and collective goods versus the individual. In R. H. Taylor (Ed.), The idea of freedom in Asia and Africa (pp. 203-261). Stanford: Stanford Univ. Press.

Habermas, J. (2001). Braucht Europe eine Verfassung? In Zeit der Übergänge. Frankfurt am Main: Suhrkamp, pp. 104-132.

Hobsbawm, E. J. (2001). Welchen Sinn hat Europa. Die Zeit, September 1, p. 40.

Höffe, O. (1999). Demokratie im Zeitalter der Globalisierung.München: C. H. Beck.

HU, S. ([1954] 1963). The significance of the new thought (1919). In S. Y Teng \& J. K. Fairbank (Eds.), China's response to the West: A documentary survey 1839-1923 (pp. 252-254). New York: Atheneum.

Huntington, S. P.(1993). The clash of civilizations? Foreign Affairs, 72(3), 22-49.

Huntington, S. P.(1996). The clash of civilizations and the remaking of world order. New York: Simon \& Schuster.

Jensen, L. M. (1997). Manufacturing confucianism: Chinese traditions \& universal civilization. Durham: Duke University Press.

Kim, N. K. (2009). European experience for East Asian integration: ideas, national interests, and the international circumstance. Asia Europe Journal, 7(2), 295-312.

Kim, Y. (2008). The East Asian community and East Asian values. Special lecture given at POSCO and at St. Petersburg University in Russia and at Regensburg University in Germany, May 21-26. Retrieved from http://www.historyfoundation.or.kr

Levenson, J. R. (1958). Confucian China and its modern fate: The problem of intellectual continuity. London: Routledge and Kegan Paul.

Levenson, J. R. (1968). Confucian China and its modern fate: A trilogy. Berkeley, Los Angeles: University of California Press.

Li, D. Z. (1978). Da Yaxiyazhuyiyu Xin Yaxiyazhuyi (Great Asianism and New Asianism). In Renmin Chunbansche (Eds.), Li Da Zhao Xuanji (Selected Works) (pp. 127-129). Beijing: Renmin Chubansche.

MacFarquhar, R. (1980). The post-confucian challenge. The Economist, February 9, pp. 67-72

Machetzki, R. (1971). Liang Ch'i-ch'ao und die Einflüssedeutscher Staatslehren auf den monarchischen Reformnationalismus in China nach 1900. Hamburg, Univ., Diss.

Masuda, W. (2000). Japan and China: Mutual representations in the modern era. (J. A. Fogel, Trans.). New York: St. Martin's Press.

Nohara, S. (1975). Anarchists and the May 4th Movement in China. Libero International, 1(January), 4-18. Retrieved from http://www.negations.net

Okakura, T. ([1903] 1920). The ideals of the East with special reference to the art of Japan. New York: Dutton.

Osterhammel, J. \& Petersson, N. P. (2000). Ostasiens Jahrhundertwende. Unterwerfung und Erneuerung in west-östlichen Sichtweisen. Geschichte und Gesellschaft. Sonderheft 18 (Das Neue Jahrhundert. Europäische Zeitdiagnosen und Zukunftsentwürfe um 1900).

Park, Y. H. (1979). Ursachen und Auswirkung des japanischen Subimperialismus: dargestellt anhand der Öffnung, Eroberung und Kolonisierung Koreas, 1876-1945. Goethe-Universität Frankfurt am Main. Thesis (Doctoral).

Perkins, M. A. (2004). Christendom and European identity: The legacy of a grand narrative since 1789. Berlin: Walter de Gruyter. 
Pieris, A. (1988). An Asian theology of liberation. Maryknoll, N.Y: Orbis Books.

Renan, E. (1993). Was ist eine Nation? In M. Jeismann \& H. Ritter (Eds.), Grenzefälle. Über neuen und alten Nationalismus (pp. 293-311). Leipzig: Reclam.

Ro, Y. C. (1989). The Korean neo-Confucianism of Yi Yulgok [With a foreward by Tu Wei-Ming]. New York: State Univ. of New York Press.

Said, E. (1978). Orientalism. London: Routledge \& Kegan Paul.

Sato, N. (2008). Confidential plan of world unification [Kondo Hisaku]. In W. T. De Bary (Ed.), Sources of East Asian tradition vol. 2: The modern period (pp. 338-339). New York: Columbia Univ. Press.

Shin, C. H. (1997). Critics of East Asianism. In C. Won-Sik \& B. Young-seo (Eds.), Dongasiainui “Dongyang” insik [Cognition of the East by Asian] (pp. 216-220). Seoul: Munhakkwa Jiseongsa.

Sun, Y. S. (1924). Pan-Asianism [Sun Yat-sen's speech on Pan-Asianism, Translation of a speech delivered in Kobe, Japan on November 28, 1924. Typed in based on a copy of Sun Yat-Sen, China and Japan: Natural friends, unnatural enemies, Shanghai: 1941 currently in the Library of Congress in Washington, D.C. USA]. Retrieved from http://en.wikisource.org

Sun, Y. S. (1965). Da Yazhouzhuyi (the Great Asianism). In Guofuquanji (Complete Works of National Father). Taipei: ZhonghuaMingguo Gejie JinianGoufu BainianDanshenghui ChoubeiWeiyuanhui, pp. 306-312.

Tanaka, S. (1993). Japan's orient: Rendering pasts into history. Berkeley and Los Angeles: University of California Press.

Tang, S. P. (2002). China and Korea in East Asia: Possibility for collective actions? In C. K. Woo \& J. W. Choi (Eds.), The Korean association of international studies [The KAIS International Conference Series no. 13 "Korea and China in the New Global System"].

Tikhonov, V. (2003). World is a battlefield: Social Darwinism as the new world model of Korean intelligentsia of the 1890s. Bochumer Jahrbuchzur Ostasien forschung, 27, 81-106.

Uchiyama, A. (2009). Translation as representation: Fukuzawa Yukichi's representation of the "others". In J. Milton \& P. Bandia (Eds.), Agents of translation (pp. 63-83). Amsterdam Philadelphia: John Benjamins B. V.

Vattimo, G. (2007). After Christianity. (L. D’Isanto trans.). New York: Columbia Univ. Press.

Wang, H. (2007). The politics of imagining Asia: A genealogical analysis. (M. A. Hale trans.). Inter-Asia Cultural Studies, 8(1), $1-33$.

Weiner, M. (1997). The invention of identity: Race and nation in prewar Japan. In F. Dekötter (Ed.), The construction of racial identities in China and Japan (pp. 96-117). London: C. Hurst \& Co..

Wittfogel, K. A. (1957). Oriental despotism: A comparative study of total power. New Haven: Yale Univ. Press. 